\title{
Opportunities to evaluate emission of particulate matter from the combustion engines of rail vehicles
}

\author{
Możliwości oceny emisji cząstek stałych z silników \\ spalinowych pojazdów szynowych
}

\begin{abstract}
The paper deals with particulate emission from the rail vehicles equipped with a combustion engine drive. Physicochemical properties of the particulate matter and the mechanisms of their emergence are described as well as their consequences exerted on the environment, with special attention paid to their impact on humans. Legal regulations related to their emission are quoted, inclusive of the latest standards (stage $V$ ) as well as the requirements relating to the measurement methods of the particulate mass and number of the particles.
\end{abstract}

Artykut dotyczy emisji czastek stałych z pojazdów szynowych, w których źródtem napędu jest silnik spalinowy. Opisano właściwości fizykochemiczne czastek stałych, mechanizmy ich powstawania oraz zaprezentowano wphyw ich oddziaływania na otoczenie, w tym bezpośrednio na człowieka. Zawarto regulacje prawne dotyczqce ich emisji wraz z określeniem najnowszych norm (etap V) oraz wymagania dotyczace metod pomiarowych pomiaru masy i liczby czastek statych.

\section{Introduction}

Development of the technology in all fields of the industry results in the need of reduction of its negative effect on the natural environment. The use of advanced techniques and their development impels permanent verification of operating conditions of the rail vehicles and analysis of the effects exerted on the natural and civilizational man's environment. The rail transport is considered to be a rapidly growing area. This results, first of all, in the need to reduce the emission of harmful exhaust components. The emission of particulate matter is liable to endanger humans significantly, giving rise to a barrier for the development of modern internal combustion engines, particularly the direct injection compression-ignition engines (CI). An important challenge for the manufacturers arises from future projected toxicity standards, requiring significantly lower particulate emission than today.

The concept of PM (Particulate Matter) has been introduced in 1970. It usually means all the solid or liquid, organic or inorganic matter that accumulates on the filter (of $99 \%$ efficiency, retaining solid particles of the dimensions exceeding $300 \mathrm{~nm}$ ) when the exhaust stream diluted with air of the temperature of $52 \pm 3^{\circ} \mathrm{C}$ passes through it. The rail vehicles play an important role in everyday human life. At present the internal combustion engines are increasingly used for various applications. Growing number of non-road vehicles contributes not only to development, but also to hazard, since combustion of fuels adversely affects

\section{Wprowadzenie}

Rozwój techniki we wszystkich dziedzinach przemysłu powoduje konieczność ograniczania jego negatywnego wpływu na środowisko naturalne. Stosowanie zaawansowanych technik i ich rozwój zmuszają do ciagłej weryfikacji warunków pracy pojazdów szynowych oraz analizy skutków ich oddziaływania na środowisko naturalne i cywilizacyjne człowieka. Transport kolejowy jest uznawana za dziedzinę rozwijającą się bardzo dynamicznie; to powoduje konieczność ograniczania przede wszystkim emisji szkodliwych składników spalin. Istotnym zagrożeniem dla ludzi jest emisja cząstek stałych, stanowiąca barierę rozwoju współczesnych silników spalinowych, w szczególności silników o bezpośrednim wtrysku paliwa silników o zapłonie samoczynnym (ZS). Ważnym wyzwaniem dla producentów są projekty kolejnych norm toksyczności, według których emisja cząstek stałych powinna być wielokrotnie mniejsza od dotychczasowej.

Pojęcie cząstek stałych PM (Particulate Matter) wprowadzono w roku 1970; najczęściej oznacza ono w pomiarach silników spalinowych całą materię stałą lub ciekłą, organiczną lub nieorganiczną, która gromadzi się na filtrze (o skuteczności 99\%, zatrzymującym cząstki stałe o wymiarach większych niż $300 \mathrm{~nm}$ ) po przejściu strumienia spalin rozcieńczonych powietrzem w temperaturze $52 \pm 3{ }^{\circ} \mathrm{C}$. Pojazdy szynowe od dawna odgrywają ważną rolę $\mathrm{w}$ codziennym życiu człowieka. Obecnie następuje zwiększenie wykorzystania silników spalinowych do różnych zastosowań; 
the human health and causes environmental pollution, smog formation and the greenhouse effect.

In the late 1990s the interest in negative impact of particulate matter on human health increased worldwide $[1,2]$. The first document confirming increased mortality caused by toxic effects of particulate matter was published in 1993 as a result of the research conducted under supervision of Dockery and others [3]. The results of these studies have been confirmed also by other works [4]. The earlier studies, e.g. those carried out by Georgius Agricola and published in "De re metallica" (around 1530) were devoted to the effect of the dust from coal mining on the miners' health.

The particulate matter is emitted mainly in the CI engines. Analysis of these engines so far manufactured and the prospects for their development allows to conclude that the carbon monoxide and hydrocarbon emission limit standards may be easily met. Nevertheless, fulfilment of the requirements related to reduction of the emission of nitrogen oxides is more difficult. The particulate emission barrier makes a critical requirement for these engines, therefore, the research devoted to toxicity reduction of the diesel engines is now focused on explaining the phenomena liable for particulate matter generation and possible reduction of their emission [5].

\section{Characteristics of particulate matter with con- sideration of its mass and number of the parti- cles}

The form, size and composition of the particles of particulate matter depend to a large extent on the place in the cylinder - exhaust system - surrounding atmosphere system, from which they are collected according to the research type, as well as on the temperature. Therefore, the most commonly used definition of particulate refers to the conditions of the emission measurement [6]. Two basic fractions of the emitted particles are distinguished that is outlined in Figures 1 and 2:

- $\mathrm{PM}_{\mathrm{SOF}}-\mathrm{SOF}$ - the Soluble Organic Fraction, i.e. the part of particulate matter of solid particles that may be extracted with dichloromethane $\mathrm{CH}_{2} \mathrm{Cl}_{2}$;

- $\mathrm{PM}_{\mathrm{SOL}}$-SOL - the Insoluble Fraction, composed mainly of solid carbon ("solid", $\mathrm{PM}_{\mathrm{C}}$ ), of the form similar to graphite.

Among the other $\mathrm{PM}_{\mathrm{SOL}}$ components there are water-soluble sulfates, water associated with sulfates, nitrates, metals, other particles containing RPM carbon (Residual Particulate Mass) [7].

The particulate matter embedded in the engine exhaust gas constitute a polydisperse system composed of the particles of various sizes, shapes and forms. Taking into account that the particles of particulate matter are of different sizes and shapes and make an irregular mixture of various chemical compounds, wzrastająca liczba pojazdów pozadrogowych jest nie tylko czynnikiem rozwoju, ale również zagrożeniem spalanie paliw negatywnie oddziałuje na zdrowie ludzkie, a także powoduje zanieczyszczenie środowiska, powstawanie smogu oraz efektu cieplarnianego. W końcu lat dziewięćdziesiątych XX wieku na całym świecie wzrosło zainteresowanie negatywnym oddziaływaniem cząstek stałych na zdrowie człowieka $[1,2]$. Pierwszy dokument stwierdzający zwiększenie śmiertelności na skutek toksycznego działania cząstek stałych opublikowano w roku 1993, w wyniku badań przeprowadzonych pod kierownictwem Dockery'ego i in. [3]. Wyniki tych badań znalazły potwierdzenie również w innych badaniach [4]. Wcześniejsze badania, np. prowadzone przez Georgiusa Agricole i opublikowane w „De re metallica” (ok. 1530 r.), dotyczyły wpływu pyłu powstającego przy wydobyciu węgla na zdrowie górników.

Emisja cząstek stałych to zjawisko występujące głównie w silnikach ZS. Na podstawie analiz dotychczas produkowanych tych silników i perspektyw ich rozwoju można stwierdzić, że nie ma problemów ze spełnieniem norm granicznych emisji tlenku wegla i węglowodorów, natomiast trudniejsze jest spełnienie wymogów ograniczających emisję tlenków azotu. Bariera emisji cząstek stałych stanowi wymogi krytyczne dla tych silników i dlatego punkt ciężkości badań nad obniżeniem toksyczności silników ZS przesunął się na wyjaśnienie zjawisk związanych $\mathrm{z}$ tworzeniem cząstek stałych i możliwościami obniżania ich emisji [5].

\section{Charakterystyka cząstek stałych pod wzglę- dem masy $i$ liczby}

Postać, wielkość i skład cząstek stałych zależą w dużej mierze od miejsca i temperatury w układzie: cylinder-układ wylotowy-otaczająca atmosfera, w którym, w zależności od rodzajów prowadzonych badań, następuje ich przechwycenie do pomiaru. Stąd też najpowszechniej przyjęty sposób definicji cząstek stałych zawiera w swym sformułowaniu człon określający warunki, w jakich dokonywany jest pomiar emisji [6]. W emitowanych cząstkach stałych rozróżnia się dwie zasadnicze frakcje, które poglądowo przedstawiono na rys. 1 i 2 :

- $\mathrm{PM}_{\mathrm{SOF}}$ - organiczna frakcja rozpuszczalna SOF (Soluble Organic Fraction), czyli ta część materii cząstek stałych, która jest poddawana ekstrakcji dwuchlorometanem $\mathrm{CH}_{2} \mathrm{Cl}_{2}$,

- $\mathrm{PM}_{\mathrm{SOL}}$ - frakcja nierozpuszczalna SOL (Insoluble Fraction), której podstawową częścią jest węgiel stały (,solid”, $\mathrm{PM}_{\mathrm{C}}$ ), będący pewną formą zbliżoną do grafitu.

Do pozostałych składników $\mathrm{PM}_{\mathrm{SOL}}$ należą: rozpuszczalne $\mathrm{w}$ wodzie siarczany, woda związana $\mathrm{z}$ siarczanami, azotany, metale, pozostałe cząstki zawierające węgiel RPM (Residual Particulate Mass) [7]. 


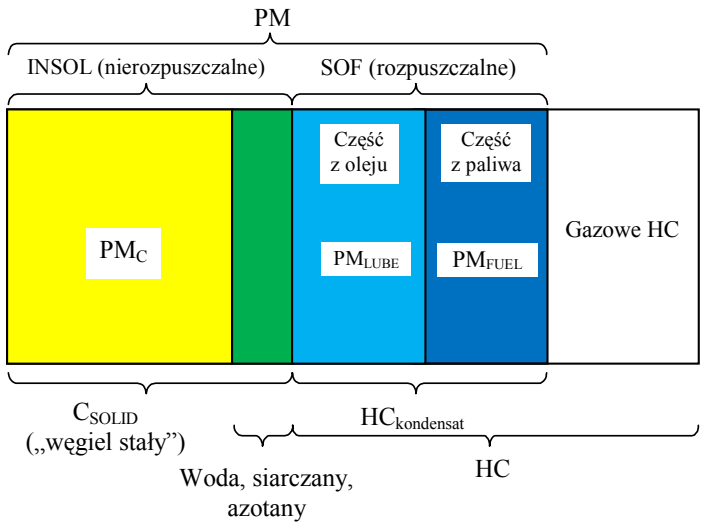

Rys. 1. Schemat budowy cząstki stałej [7]

Fig. 1. Scheme of the solid particle structure [7] nierozpuszczalne, rozpuszczalne ... = insoluble, soluble, part from oil, part from fuel, gas, solid carbon, Water, sulfates, nitrates

they cannot be clearly physically or chemically defined $[9,10]$. The nature of the particles, mainly the distribution of their geometric dimensions, their number and morphology, is important for evaluating their impact on the environment and human body.

The particulate matter emitted by all the internal combustion engines (Fig. 3) include solids and liquids that condense depending on physical conditions (i.e. temperature, pressure). Emitted solids include two main fractions: SOL (insoluble fraction, composed mainly of solid carbon of a graphite-similar form), that may be extracted with dichloromethane $\mathrm{CH}_{2} \mathrm{Cl}_{2}$, and SOF (soluble fraction). The other SOL components include water-soluble sulphates, water associated with sulphates, nitrates, metals and other carbon-containing particles $[11,12]$. Individual particles combine into agglomerates the properties of which (e.g. density, total area, size distribution, chemical composition) differ from those of the particles. Sulfur occurs in this fraction mainly due to its content in the fuel (at present $10 \mathrm{ppm}$ ). On the other hand, the exhaust gas may include sulfur in the form of $\mathrm{SO}_{2}$ and $\mathrm{SO}_{3}$, thus generating sulphurous acid and sulfates in the emitted particles. The mass share of the SOF fraction in the particles may range from $10 \%$ to $90 \%$, usually growing with decreasing engine load and decreasing exhaust gas temperature [13, 14].

Among many parameters of the particles of particulate matter the diameter is the most important. According to its value the particles are classified to a given type (Fig. 4) [16, 17]. The current quick development of the research techniques enabled to separate and to classify the particles of various dimensions (the aerodynamic diameter was adopted as a characteristic feature): $\mathrm{D}<10 \mu \mathrm{m}$ - large particles (designated as PM10), $\mathrm{D}<2.5 \mu \mathrm{m}$ - fine particles (PM2.5), $\mathrm{D}<100 \mathrm{~nm}$ - very fine particles and $\mathrm{D}<50 \mathrm{~nm}$ nanoparticles. Internal combustion engines emit the

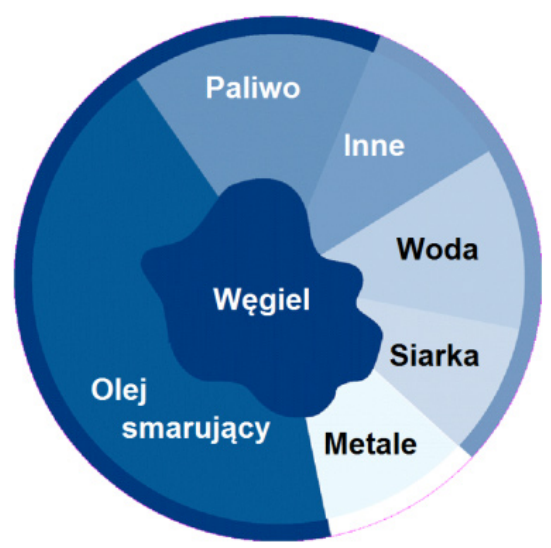

Rys. 2. Cząstka stała - węglowy rdzeń ze skondensowanymi i zaabsorbowanymi substancjami [8]

Fig. 2. A solid particle - a carbon core surrounded with the condensed and absorbed matter [8]

Wegiel, Paliwo, .... = Carbon, Fuel, Others, Water, Sulfur, Metals, Lubricating oil

Cząstki stałe zawarte w spalinach silnikowych stanowią system polidyspersyjny, składający się z cząstek o różnych wymiarach i kształcie oraz postaci występowania. Ze względu na trudności opisu cząstek stałych, gdyż są one nieregularną mieszaniną różnych związków chemicznych oraz są niejednorodne pod względem wielkości i kształtu, nie mogą być jednoznacznie zdefiniowane fizycznie ani chemicznie [9, 10]. Natura cząstek, głównie rozkład wymiarów geometrycznych, liczba cząstek i ich morfologia są ważne ze względu na ocenę ich wpływu na środowisko i ciało ludzkie.

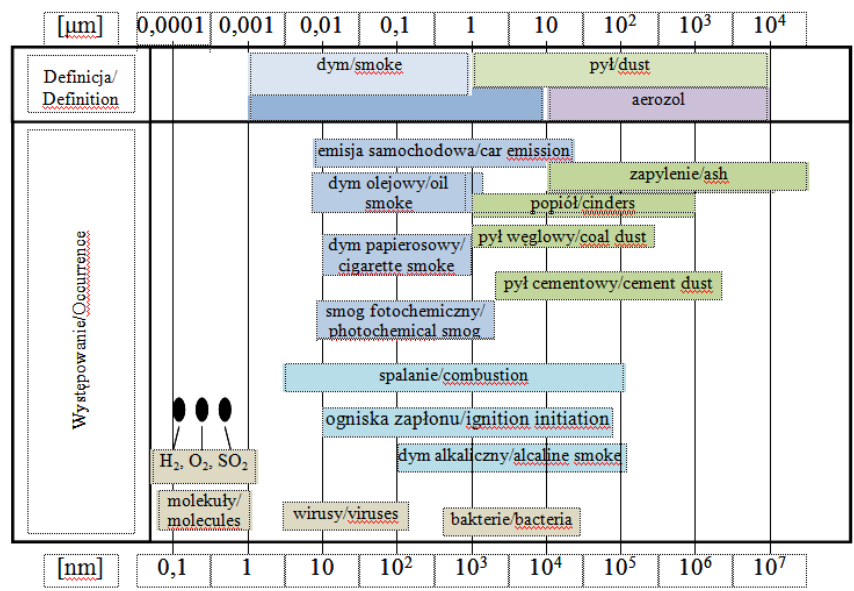

Rys. 3. Rozmiary i występowanie cząstek w środowisku [15]

Fig. 3. The sizes and occurrence of particles in the environment

W skład cząstek stałych emitowanych przez wszystkie silniki spalinowe (rys. 3) wchodzą ciała stałe oraz ciekłe, które zależnie od warunków fizycznych (temperatura, ciśnienie) ulegają kondensacji. W emitowanych cząstkach stałych rozróżnia się dwie zasadnicze frakcje: SOL (frakcja nierozpuszczalna, której podstawowym składnikiem jest węgiel stały, będący formą zbliżoną do grafitu), która jest ekstrahowana za pomocą dichlorometanu $\mathrm{CH}_{2} \mathrm{Cl}_{2}$, oraz SOF 
particles with the diameter exceeding $10 \mathrm{~nm}$ (Fig. 5). Exhaust gases of the CI engines contain the largest number of the solid particles having diameters of 60 $100 \mathrm{~nm}$. Their mass amounts about to $20 \%$ of all the particles [16].

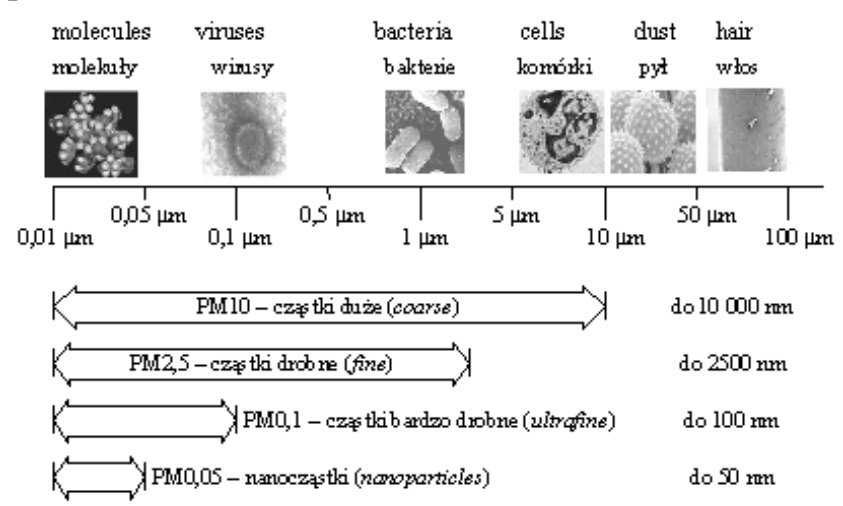

Rys. 4. Klasyfikacja cząstek stałych na podstawie ich wymiarów [18]

Fig. 4. Classification of the solid particles based on their dimensions [18]

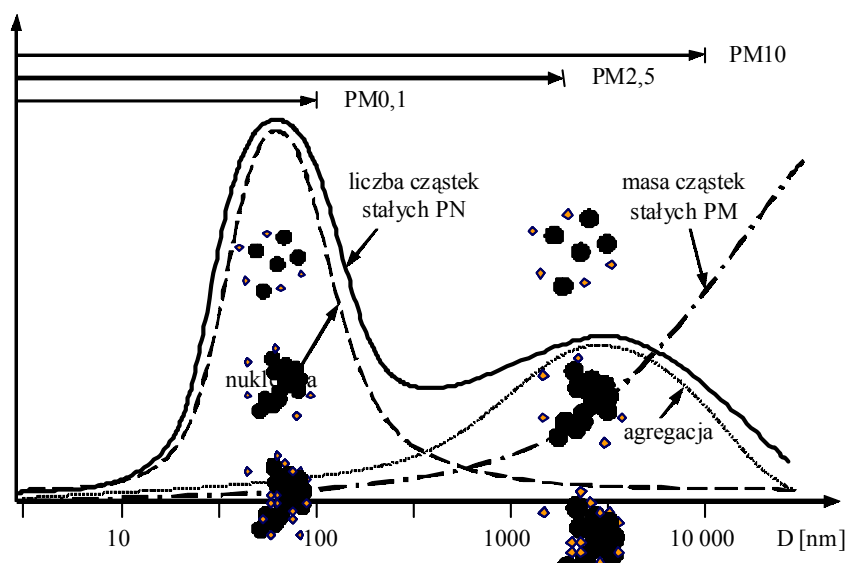

Liczba, masa czastek. .= The number and mass of the PM particles, number of the PN particles, nucleation, mass of the PM particles, aggregation

Rys. 5. Rozkład wielkości cząstek powstałych w wyniku zarodkowania i agregacji w spalinach silnika spalinowego [19]

Fig. 5. Size distribution of the particles ensuing from nucleation and aggregation in the exhaust gas of a combustion engine [19]

The PM10 symbol theoretically denotes the particles of the diameter below $10 \mu \mathrm{m}$. Nevertheless, the impactors (or other classifiers) do not achieve in practice the efficiency allowing for passing of the particles with the diameter up to $10 \mu \mathrm{m}$ (they usually pass the particles of the diameter of up to $15 \mu \mathrm{m})$. It is assumed that PM10 (or PM5, PM2.5, respectively) corresponds to 50-percent transmission efficiency of the particles with the diameters of $10 \mu \mathrm{m}$ or $5 \mu \mathrm{m}$ and $2.5 \mu \mathrm{m}$, respectively.

The change in physical properties of the solid particles depends on the processes they are subjected to (Table 1). Nucleation occurs in the engine combustion chamber and is significantly affected by the ignition and combustion parameters. Nucleation of hy- (frakcja rozpuszczalna). Do pozostałych składników SOL należą: rozpuszczalne w wodzie siarczany, woda związana z siarczanami, azotany, metale i pozostałe cząstki zawierające węgiel $[11,12]$. Pojedyncze cząstki łączą się w aglomeraty; właściwości aglomeratów (m.in. gęstość, powierzchnia całkowita, rozkład wielkości, skład chemiczny) są odmienne niż pojedynczych cząstek. Występowanie siarki w tej frakcji jest związana przede wszystkim $\mathrm{z}$ jej zawartością w paliwie (obecnie $10 \mathrm{ppm}$ ). Siarka $\mathrm{w}$ spalinach może występować jako $\mathrm{SO}_{2} \mathrm{i} \mathrm{SO}_{3}$, tworząc $\mathrm{w}$ emitowanych cząstkach kwas siarkawy oraz siarczany. Udział frakcji SOF w masie cząstek może wahać się od $10 \%$ do $90 \%$, przy czym zwykle wzrasta wraz ze zmniejszaniem obciążenia silnika $\mathrm{w}$ miare zmniejszenia temperatury spalin $[13,14]$.

Spośród wielu parametrów cząstek stałych najważniejsza jest średnica; w zależności od jej wartości kwalifikuje się cząstki do danego typu (rys. 4) [16, 17]. Dotychczasowy szybki rozwój technik badawczych umożliwił wyodrębnienie i sklasyfikowanie cząstek stałych o różnych wymiarach (jako charakterystyczną przyjęto średnicę aerodynamiczną): $\mathrm{D}<10 \mu \mathrm{m}-$ cząstki duże (oznaczane jako PM10), D $<2,5 \mu \mathrm{m}-$ cząstki drobne (PM2,5), D < $100 \mathrm{~nm}$ - cząstki bardzo drobne oraz D $<50 \mathrm{~nm}$ - nanocząstki. Silniki spalinowe emituja cząstki o średnicy większej niż $10 \mathrm{~nm}$ (rys. 5). W spalinach silników ZS występuje najwięcej cząstek stałych o średnicach $60-100 \mathrm{~nm}$; ich masa wynosi około $20 \%$ masy wszystkich cząstek [16].

Symbol PM10 oznacza teoretycznie cząstki stałe o średnicy mniejszej niż $10 \mu \mathrm{m}$, jednakże w praktyce impaktory (lub inne klasyfikatory) nie osiagają sprawności umożliwiającej przepuszczanie tylko cząstek o średnicy do $10 \mu \mathrm{m}$ (zwykle przepuszczają cząstki o średnicy do $15 \mu \mathrm{m}$ ). Przyjęto, że PM10 (lub odpowiednio PM5, PM2,5) uzyskuje się przy 50procentowej sprawności przepuszczania cząstek o średnicy $10 \mu \mathrm{m}$ lub odpowiednio $5 \mu \mathrm{m}$ i $2,5 \mu \mathrm{m}$.

Zmiana właściwości fizycznych cząstek stałych zależy od procesów, którym one podlegają (tab. 1). Nukleacja (zarodkowanie) zachodzi w komorze spalania silnika; znaczący wpływ na nią mają parametry zapłonu i spalania. Zarodkowanie węglowodorów wraz z innymi związkami (m.in. $\mathrm{z}$ dodatkami do paliw i w bardzo małym stopniu z siarką) odbywa się w wyniku chłodzenia (np. rozcieńczania) spalin w układzie wylotowym silnika. Wzrost wielkości cząstek zależy głównie od stopnia ich aglomeracji, na co mają wpływ pierwotne stężenie liczbowe cząstek oraz czas koagulacji. Szybkość koagulacji jest proporcjonalna do kwadratu początkowego stężenia liczbowego cząstek stałych $(\mathrm{t}=0)$ oraz współczynnika koagulacji K [20].

Skład emitowanych cząstek, a także ich liczba i wielkość zależą od miejsca i sposobu pobierania próbek spalin. Zgodnie z obowiązującymi w Europie i USA normami próbki do analizy cząstek stałych po- 
drocarbons together with other compounds (inclusive of fuel additives and to a very small extent with sulfur) takes place as a result of cooling (e.g. dilution) of the exhaust gases in the engine exhaust system. The increase in particle size depends chiefly on the agglomeration degree, affected by the initial number concentration of the particles and the coagulation time. The coagulation rate is proportional to the square of the initial number concentration of the particulates $(t=0)$ and the coagulation coefficient $K$ [20]. biera się po rozcieńczeniu spalin powietrzem i ochłodzeniu mieszaniny do temperatury $52^{\circ} \mathrm{C}$. Wtedy lotne składniki SOF ulegają adsorpcji, kondensacji oraz nukleacji. Transformacja ta powoduje zmianę udziału SOF $\mathrm{w}$ istniejących już cząstkach oraz powstanie nowych czastek o charakterze stałym lub ciekłym. Aglomeracja nie powoduje zmiany masy cząstek stałych ani ich składu chemicznego, jednakże w jej efekcie zmienia się liczba cząstek, rozkład wielkości oraz skład frakcyjny. Mechanizm aglomeracji nie ma wpły-

Tablica 1. Zmiana właściwości fizycznych cząstek stałych [21]

Table 1. The change in physical properties of the solid particles [21]

\begin{tabular}{|c|c|c|c|}
\hline $\begin{array}{l}\text { Efekt fizyczny } \\
\text { Physical effect }\end{array}$ & $\begin{array}{c}\text { Zmiana parametru } \\
\text { Change in the parameter }\end{array}$ & $\begin{array}{c}\text { Występowanie } \\
\text { Occurrence }\end{array}$ & $\begin{array}{l}\text { Schemat } \\
\text { Scheme }\end{array}$ \\
\hline $\begin{array}{l}\text { Nukleacja/zarodkowanie } \\
\text { Nucleation }\end{array}$ & $\begin{array}{c}\text { liczba cząstek stałych } \\
\text { number of solid particles }\end{array}$ & $\begin{array}{c}\text { komora spalania silnika } \\
\text { engine combustion chamber }\end{array}$ & \\
\hline $\begin{array}{l}\text { Aglomeracja/koagulacja } \\
\text { Agglomeration/coagulation }\end{array}$ & $\begin{array}{c}\text { powierzchnia cząstek } \\
\text { Surface area of the particles }\end{array}$ & $\begin{array}{l}\text { układ wylotowy silnika } \\
\text { engine exhaust system }\end{array}$ & \\
\hline $\begin{array}{l}\text { Dyfuzja/przenikanie } \\
\text { Diffusion }\end{array}$ & $\begin{array}{l}\text { zmiana masy } \\
\text { change in mass }\end{array}$ & $\begin{array}{l}\text { układ wylotowy silnika, } \\
\text { engine exhaust system } \\
\text { pobór próbki spalin } \\
\text { sampling of the exhaust } \\
\text { gases }\end{array}$ & \\
\hline $\begin{array}{l}\text { Adsorpcja/kondensacja } \\
\text { Adsorption/condensation }\end{array}$ & $\begin{array}{l}\text { zwiększenie masy } \\
\text { growth of the mass }\end{array}$ & $\begin{array}{l}\text { tunel rozcieńczający } \\
\text { dilution tunel }\end{array}$ & \\
\hline
\end{tabular}

The composition, number and sizes of the emitted particles depend on the place and method of sampling of the exhaust gas. According to the standards in force in Europe and the USA, the samples designed for analysis of the particulate matter are collected after dilution of the exhaust gases with air and cooling the mixture to a temperature of $52^{\circ} \mathrm{C}$. Then the volatile SOF components are adsorbed, condensed and nucleated. Such a transformation changes the share of SOF in already existing particles and results in formation of new particles of solid or liquid nature. Agglomeration does not change the mass nor chemical composition of the solid particles, however, as a result, the number of particles, size distribution and fractional composition are changed. The agglomeration mechanism does not change the mass of the solid particles, but it largely affects their number and size distribution. In result of the diffusion mechanism the mass of solid particles changes (grows or falls). This is due to the effect of the concentration gradients of particular fractions of the particles. However, the adsorption and condensation contributes to the increase in mass of the particles, in result of reduction of the exhaust gas temperature in the engine exhaust system. The solid particles emitted from CI engines consist mainly of carbon with absorbed hydrocarbons in liquid form (hydrocarbon condensate). The publications, e.g. Kittelson [17], present an opinion supported by the research results of CI engines that the carbon part of a solid particle (i.e. its skeleton) can constitute $20-45 \%$ of the whole wu na masę cząstek stałych, natomiast ma bardzo duży wpływ na ich liczbę i rozkład wielkości. W wyniku mechanizmu dyfuzji zmienia się masa cząstek stałych (zwiększa lub zmniejsza); jest to efektem występowania gradientów stężenia poszczególnych frakcji cząstek stałych. Natomiast w wyniku adsorpcji i kondensacji masa cząstek się zwiększa - co jest efektem obniżania się temperatury spalin w układzie wylotowym silnika. Cząstki stałe emitowane z silników ZS składają się głównie $\mathrm{z}$ węgla z zaabsorbowanymi węglowodorami w postaci ciekłej (kondensatem węglowodorowym). W publikacjach, np. Kittelsona [17], przeważa pogląd poparty wynikami badań silników ZS, że część węglowa cząstki stałej (jej szkielet) może stanowić $20-45 \%$ masy całej cząstki stałej. Pozostałą część stanowią niespalony olej smarujący (25\%), paliwo (do 10\%) oraz związki siarki i wody (łącznie przy bardzo małej zawartości siarki - mniejszej niż 10 ppm) oraz innych substancji. Według innych badaczy [22] skład cząstek stałych może być wyrażony w innych proporcjach (tab. 2).

Nanocząstki stanowią większość całkowitej liczby cząstek emitowanych przez silnik i bardzo małą część ich całkowitej masy. Dotychczasowy masowy sposób wyznaczania emisji cząstek nie jest wystarczający do oceny emisji nanoczastek [23]. Z wprowadzeniem ograniczeń emisji nanocząstek będą się wiązać z pewnością inne metody pomiaru, które obecnie są intensywnie badane. 
Tablica 2. Typowy sklad (charakterystyka) cząstek stałych [22]

Table 2. Typical composition (characteristics) of particulate matter [22]

\begin{tabular}{|c|c|c|c|c|}
\hline $\begin{array}{l}\text { Parametr } \\
\text { Parameter }\end{array}$ & $\begin{array}{l}\text { Węgiel } \\
\text { Carbon } \\
\end{array}$ & $\begin{array}{l}\text { Popiół } \\
\text { Ash }\end{array}$ & $\begin{array}{l}\text { Związki organiczne } \\
\text { Organic compounds }\end{array}$ & $\begin{array}{l}\text { Związki kwasowe } \\
\text { Acidic compounds }\end{array}$ \\
\hline $\begin{array}{l}\text { Forma } \\
\text { Form }\end{array}$ & $\begin{array}{c}\text { części stałe, } \\
\text { związki nieulotne } \\
\text { solids, non-volatile } \\
\text { compounds } \\
\end{array}$ & $\begin{array}{c}\text { części stałe, } \\
\text { związki nieulotne } \\
\text { solids, non-volatile } \\
\text { compounds } \\
\end{array}$ & $\begin{array}{c}\text { ciecz, } \\
\text { związki lotne } \\
\text { liquid, } \\
\text { volatile compounds } \\
\end{array}$ & $\begin{array}{c}\text { ciecz, } \\
\text { związki lotne } \\
\text { liquid, } \\
\text { volatile compounds }\end{array}$ \\
\hline $\begin{array}{l}\text { Wymiar [nm] } \\
\text { Dimension [nm] }\end{array}$ & $30-150$ & $2-10$ & $2-30$ & $2-30$ \\
\hline $\begin{array}{l}\text { Gęstość }\left[\mathrm{g} / \mathrm{cm}^{3}\right] \\
\text { Density }\left[\mathrm{g} / \mathrm{cm}^{3}\right]\end{array}$ & $1,8-1,9$ & 2,6 & $0,8-0,9$ & 1,1 \\
\hline $\begin{array}{l}\text { Skład [\%] } \\
\text { Composition [\%] }\end{array}$ & $\begin{array}{l}\mathrm{C}: 85-98,5 \\
\text { - O: } 0,4-14 \\
\text { - H: } 0,3-1,5 \\
\end{array}$ & $\begin{array}{l}\text { - } \mathrm{CaSO}_{4}: \text { ok. } 90 \\
\text { - } \mathrm{Ca}\left(\mathrm{PO}_{4}\right)_{\mathrm{n}}: \text { ok. } 5\end{array}$ & $\begin{array}{l}\text { - paliwo: }>60 \\
\text { - olej (ciecz): < } 5 \\
\text { - olej (gaz): }<10\end{array}$ & $\mathrm{H}_{2} \mathrm{SO}_{4} ? 7 \mathrm{H}_{2} \mathrm{O}$ \\
\hline $\begin{array}{l}\text { Toksyczność } \\
\text { Toxicity }\end{array}$ & $\begin{array}{l}\text { tak } \\
\text { yes }\end{array}$ & $\begin{array}{l}\text { nie } \\
\text { no }\end{array}$ & $\begin{array}{l}\text { tak/nie } \\
\text { yes/no }\end{array}$ & $\begin{array}{c}\text { nie } \\
\text { no }\end{array}$ \\
\hline $\begin{array}{l}\text { Udział [\%] } \\
\text { Percentage } \\
\text { - silniki Stage III } \\
\text { - dane literaturowe } \\
\text { - Stage III engines } \\
\text { - literature data } \\
\end{array}$ & $\begin{array}{l}74 \\
41\end{array}$ & $\begin{array}{c}4 \\
13\end{array}$ & $\begin{array}{l}21 \\
32\end{array}$ & $\begin{array}{c}1 \\
14\end{array}$ \\
\hline
\end{tabular}

mass of the particle. The remaining part consists of unburned lubricating oil (25\%), fuel (up to $10 \%$ ) as well as sulfur and water compounds (together with very low sulfur content - below $10 \mathrm{ppm}$ ) and other substances. According to other researchers [22], composition of the solid particles may be characterized by other proportions (Table 2).

Nanoparticles represent a majority of total number of the particles emitted by the engine and only a very small part of their total mass. The current comprehensive method of determining the particle emission does not allow to evaluate the emission of nanoparticles [23]. Other measurement methods being at present extensively studied should certainly enable to implement the restrictions on the nanoparticle emission.

\section{The regulations related to particulate matter emission from the non-road vehicles}

At present an increasing emphasis is being put on reducing emission from this group of vehicles, not subjected to the regulations for many years. The vehicles not belonging to the categories $\mathrm{M}, \mathrm{N}$ and $\mathrm{L}$ are often called non-road or non-road application vehicles. Implementation of the Directive 97/68/EC [24] was important for development of the provisions related to the emission from the non-road vehicles. Its scope of application differed from the arrangements set out in the Regulation 96.00. It was used in case of the vehicle engines, devices and machines generally called "non-road mobile machinery". In accordance with the definition the "non-road mobile machinery" included mobile machinery (not only self-propelled ones), the mobile industrial equipment and the vehicles not intended for road transport of people and goods, provided with internal combustion engines. The scope of application of the Basic Directive 97/68/EC covers the CI engines with maximum power not less than $18 \mathrm{~kW}$, but not exceeding $560 \mathrm{KW}$

\section{Przepisy dotyczące emisji cząstek stalych po- jazdów pozadrogowych}

Obecnie kładzie się coraz większy nacisk na zmniejszenie emisji zanieczyszczeń z tej grupy pojazdów, która przez wiele lat nie była objęta przepisami. Pojazdy inne niż kategorii M, N i L są często nazywane pojazdami pozadrogowymi lub o zastosowaniach pozadrogowych. Istotne w rozwoju przepisów o emisji zanieczyszczeń $\mathrm{z}$ pojazdów pozadrogowych było wprowadzenie dyrektywy 97/68/WE [24]. Jej zakres stosowania różnił się od ustalonego $\mathrm{w}$ regulaminie 96.00. Stosowano ją do silników pojazdów, urządzeń i maszyn nazywanych ogólnie „niedrogowymi maszynami ruchomymi" (non-road mobile machinery). Zgodnie z definicją do „niedrogowych maszyn ruchomych" zaliczano maszyny ruchome (nie tylko samobieżne), ruchome wyposażenie przemysłowe i pojazdy nieprzeznaczone do transportu osób i ładunków na drogach, wyposażone w silniki spalinowe. Zakresem stosowania dyrektywy podstawowej 97/68/WE objęto silniki ZS, mające moc maksymalną nie mniejszą niż $18 \mathrm{~kW}$, lecz nieprzekraczającą $560 \mathrm{~kW}$, pracujące przy zmiennej prędkości obrotowej. Do tych pojazdów i maszyn należały między innymi:

- przemysłowe urządzenia wiertnicze,

- urządzenia budowlane, w tym ładowarki kołowe, spycharki, ciąniki gąsienicowe, ładowarki gąsienicowe, pozadrogowe samochody ciężarowe, koparki hydrauliczne itd.,

- urządzenia rolnicze, rotacyjne maszyny do uprawy roli,

- urządzenia stosowane w gospodarce leśnej,

- samojezdne pojazdy rolnicze (z wyjątkiem ciagników rolniczych),

- urządzenia do naprawy dróg (równiarki silnikowe, walce drogowe, równiarki do asfaltu itp.),

- pojazdy do odśnieżania dróg,

- urządzenia do wspomagania naziemnego na lotniskach, 
$\mathrm{kW}$, operating at variable rotation speeds. These vehicles and machines included, among others:

- industrial drilling equipment;

- construction equipment, including wheel loaders, bulldozers, caterpillar tractors, crawler loaders, off-road trucks, hydraulic excavators, etc.;

- agricultural equipment, rotary tillage machines;

- the devices designed for forestry;

- self-propelled agricultural vehicles (except agricultural tractors);

- road repair equipment (motor graders, road rollers, asphalt graders, etc.);

- snow clearing vehicles;

- ground support equipment at the airports;

- mobile cranes.

According to the terminology used in Poland [25, 26], the above-mentioned vehicles and machines are recognized as special and low-speed vehicles. Special vehicle engines were approved according to the Directives 88/77/EC [25] and 2005/55/EC [26]. The Directive 2004/26/EC [27] amending the 97/68/EC [24] significantly expanded the term "non-road mobile machinery" and the scope of use of these machines. This directive is currently in force and covers the engines:

- CI diesel engines designed for vehicles and machines, having maximum power of not less than $19 \mathrm{~kW}$, but not exceeding $560 \mathrm{~kW}$, operating at variable rotational speed;

- CI diesel engines designed for vehicles and machines, having maximum power of not less than $19 \mathrm{~kW}$, but not exceeding $560 \mathrm{~kW}$, operating at a constant rotational speed;

- SI engines fueled with petrol, intended for machines and equipment, having maximum power not exceeding $19 \mathrm{~kW}$;

- CI diesel engines for diesel locomotives and railway motor coaches;

- CI diesel engines designed for inland waterway vessels.

Agricultural tractors are not referred to in the Directive $97 / 68 / \mathrm{EC}$ as in the EU system they are covered by other legal regulations. According to the Directive $97 / 68 / \mathrm{EC}$ the approval may be granted for an engine type or for an engine family. The definition of the engine type and family is similar to the definition related to the engines of heavy vehicles belonging to $\mathrm{M}$ and $\mathrm{N}$ categories. The following tests of the lowspeed vehicles are required by the Directive 97/68/EC:

- stationary test of NRSC (non-road stationary cycle) emission;

- dynamic test of NRTC (non-road transient cycle) emission;

- durability test.

The agreed requirements relate to:

\section{- dźwigi ruchome.}

W terminologii stosowanej w Polsce $[25,26]$ wyżej wymienione pojazdy i maszyny zalicza się do pojazdów specjalnych i wolnobieżnych. Silniki pojazdów specjalnych homologowano według dyrektyw 88/77/WE [25] i 2005/55/WE [26]. W dyrektywie 2004/26/WE [27], nowelizującej 97/68/WE [24] znacznie rozszerzono termin ,niedrogowe maszyny ruchome" i zakres stosowania tych maszyn. Dyrektywa ta obowiązuje obecnie i są nią objęte silniki:

- ZS zasilane olejem napędowym, przeznaczone do pojazdów i maszyn, mające moc maksymalną nie mniejszą niż $19 \mathrm{~kW}$, lecz nieprzekraczającą $560 \mathrm{~kW}$, pracujące przy zmiennej prędkości obrotowej,

- ZS zasilane olejem napędowym, przeznaczone do maszyn, mające moc maksymalną nie mniejszą niż $19 \mathrm{~kW}$, lecz nieprzekraczającą $560 \mathrm{~kW}$, pracujące przy stałej prędkości obrotowej,

- ZI zasilane benzyna, przeznaczone do maszyn i urządzeń, mające moc maksymalną nieprzekraczającą $19 \mathrm{~kW}$,

- ZS zasilane olejem napędowym przeznaczone do lokomotyw spalinowych i kolejowych wagonów spalinowych,

- ZS zasilane olejem napędowym, przeznaczone do jednostek pływających żeglugi śródlądowej.

Dyrektywą 97/68/WE nie objęto ciągników rolniczych, dla których w systemie UE obowiązują oddzielne akty prawne. Zgodnie z dyrektywą 97/68/WE homologacja może być udzielona dla typu silników lub dla rodziny silników. Definicja typu i rodziny jest podobna do definicji dla silników pojazdów ciężkich kategorii M i N. W dyrektywie 97/68/WE ustalono dla pojazdów wolnobieżnych następujące testy:

- stacjonarny emisji zanieczyszczeń NRSC (nonroad stationary cycle),

- dynamiczny emisji zanieczyszczeń NRTC (nonroad transient cycle),

- próbę trwałości.

Ustalone wymagania dotyczą:

- emisji zanieczyszczeń gazowych (CO, HC, $\mathrm{NO}_{\mathrm{x}}, \mathrm{HC}+\mathrm{NO}_{\mathrm{x}}$ ),

- emisji cząstek stałych.

Zasady badań i metoda pomiaru emisji w testach stacjonarnym i dynamicznym są zbliżone do występujących $\mathrm{w}$ ich odpowiednikach dla silników pojazdów ciężkich kategorii M i N. Badania są prowadzone na silnikowym stanowisku dynamometrycznym. Różnice są przede wszystkim w cyklach pracy silnika. Należy podkreślić, że cykle te nie są reprezentatywne dla ruchu pojazdów wolnobieżnych na drodze. Ustalono je jako średnie dla maszyn roboczych o różnym zastosowaniu. Cykl stacjonarny NRSC pokazano na rys. 6 , a cykl NRTC - na rys. 7 (cykl znormalizowany podobnie jak ETC). W teście dynamicznym wykonuje się dwa pomiary: pierwszy po rozruchu nienagrzanego 
- emission of gaseous pollutants $\left(\mathrm{CO}, \mathrm{HC}, \mathrm{NO}_{\mathrm{x}}\right.$, $\mathrm{HC}+\mathrm{NO}_{\mathrm{x}}$ )

- particulate matter emission.

The test principles and the method of emission measurement during stationary and dynamic tests are similar to those agreed for their equivalents for the engines of heavy vehicles of categories $\mathrm{M}$ and $\mathrm{N}$. The tests are carried out on an engine dynamometer. The differences consist, first of all, in the engine work cycles. It should be noticed that the cycles are not representative for low-speed vehicles moving on the road. They were determined as average values for working machines of various applications. The NRSC stationary cycle is shown in Fig. 6, while the NRTC cycle in Fig. 7 (standard cycle similar to the ETC). During the dynamic test two measurements trials are made: the first one after start of an engine not warmed up, while the second one -20 min after stopping the engine in the first cycle, i.e. after starting a warmed up engine. The weighted average of these two measurements is considered as a final result, with the weight factors equal to 0.1 for the first measurement and 0.9 for the second one. The Directive 97/68/EC determines five levels of the pollutant emission requirements, referred to as the stages, denoted as I, II, IIIA, IIIB and IV. At each stage the engines were divided into classes depending on the maximum power. The allowable values at each stage and their effective dates depend on the engine class. The basic directive 97/68/EC imposed two requirement stages, denoted as I and II, for the low-speed vehicles. The stage I (classes A, B, C) was applied for CI engines with a maximum net power from 37 to $560 \mathrm{~kW}$. In case of the stage II (classes D, E, F, G) the minimum power was reduced to $18 \mathrm{~kW}$. The allowed values have been reduced, especially for $\mathrm{NO}_{\mathrm{x}}$ (by 24-35\%) and PM (by 53-63\%). The tests in both stages were carried out only according to the NRSC routine. The Directive 2004/26/EC, amending the 97/68/EC, implemented three new requirement stages, denoted by IIIA, IIIB and IV (Table 3). In case of the low-speed vehicles it is applied for $\mathrm{CI}$ engines with a maximum net power of 19 to $560 \mathrm{~kW}$. The minimum power has been increased from 18 to $19 \mathrm{~kW}$ in order to unify the Directive with the US regulations. The test principles are as follows:

- At the IIIA stage the NRSC test is used, both for measurement of the emission of gaseous pollutants and solid particulate matter. The NRTC test is applied at the manufacturer's request.

- At the IIIB stage the NRSC test is used for measurement of the emission of gaseous pollutants, while the NRTC test for measurement of solid particulate emission. The NRTC test is also applied for measurement of the emission of gaseous pollutants at the manufac silnika, natomiast drugi - 20 min po zatrzymaniu silnika w cyklu pierwszym, a więc po rozruchu nagrzanego silnika. Jako wynik końcowy przyjmuje się średnią ważoną $\mathrm{z}$ tych dwóch pomiarów, przy czym współczynniki udziału wynoszą: 0,1 dla pomiaru pierwszego i 0,9 dla drugiego. W dyrektywie 97/68/WE ustalono pięć poziomów wymagań odnośnie do emisji zanieczyszczeń zwanych etapami, oznaczonych I, II, IIIA, IIIB i IV. W każdym z etapów silniki podzielono na klasy $\mathrm{w}$ zależności od mocy maksymalnej. Wartości dopuszczalne w każdym $\mathrm{z}$ etapów i daty ich obowiązywania zależą od klasy silnika. W dyrektywie podstawowej 97/68/WE dla silników pojazdów wolnobieżnych ustalono dwa etapy wymagań oznaczone I i II. Etap I (klasy A, B, C) stosowano do silników ZS o mocy maksymalnej netto od 37 do $560 \mathrm{~kW}$. W etapie II (klasy D, E, F, G) minimalną moc zmniejszono do $18 \mathrm{~kW}$. Wartości dopuszczalne obniżono, szczególnie dla $\mathrm{NO}_{\mathrm{x}}$ (о 24-35\%) i PM (o 53-63\%). Badania w obu etapach prowadzono tylko w teście NRSC. W dyrektywie 2004/26/WE, nowelizującej 97/68/WE, wprowadzono trzy nowe etapy wymagań oznaczone IIIA, IIIB i IV (tab. 3). Dla pojazdów wolnobieżnych stosuje się ją do silników ZS o mocy maksymalnej netto od 19 do $560 \mathrm{~kW}$. Moc minimalną zwiększono z 18 do $19 \mathrm{~kW}$ w celu unifikacji z przepisami amerykańskimi. Zasady badań są następujące:

- w etapie IIIA stosuje się test NRSC zarówno do pomiaru emisji zanieczyszczeń gazowych, jak i cząstek stałych; na wniosek producenta stosuje się test NRTC,

- w etapie IIIB stosuje się test NRSC do pomiaru emisji zanieczyszczeń gazowych, a test NRTC do pomiaru emisji cząstek stałych; na wniosek producenta stosuje się test NRTC także do pomiaru emisji zanieczyszczeń gazowych,

- w etapie IV stosuje się test NRSC do pomiaru emisji zanieczyszczeń gazowych, a test NRTC do pomiaru emisji cząstek stałych; na wniosek producenta stosuje się test NRTC także do pomiaru emisji zanieczyszczeń gazowych.

Pomiary emisji powinny być przeprowadzone co najmniej na początku próby trwałości po dotarciu silnika i na jej końcu. Stosuje się dwa rodzaje współczynników pogorszenia emisji DF: addytywne - określone jako różnica wyników pomiarów na końcu i na początku próby; współczynniki te dodaje się do wartości emisji zmierzonej w odpowiednim teście oraz multiplikatywne - określone jako stosunek wyników pomiarów na końcu i na początku próby; wartości zmierzone emisji w odpowiednim teście są mnożone przez te współczynniki. Jeśli współczynnik addytywny nie przekracza 0 lub multiplikatywny 1 , to nie prowadzi się korekty wartości zmierzonych w etapach IIIA, IIIB i IV. Współczynniki multiplikatywne określa się, gdy silnik jest wyposażony w urządzenia do ograniczenia 
turer's request.

- At the IV stage the NRSC test is used for measurement of the emission of gaseous pollutants, while the NRTC test for measurement of solid particulate emission. The NRTC test is also applied for measurement of the emission of gaseous pollutants at the manufacturer's request.

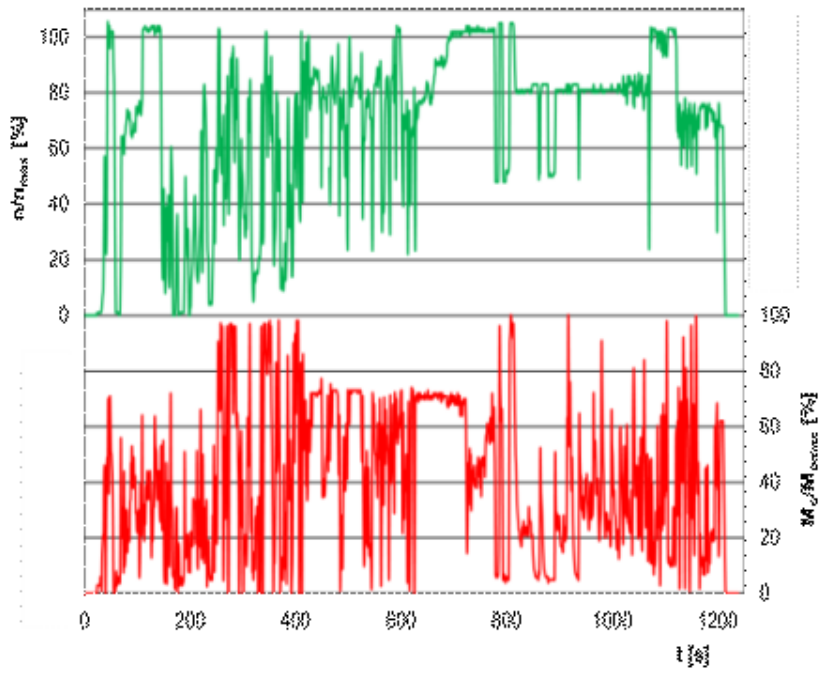

Rys. 7. Znormalizowany cykl dynamiczny NRTC [28]

Fig. 7. Normalized dynamic cycle NRTC [28] emisji w układzie wylotowym (reaktor katalityczny, wtrysk powietrza do układu wylotowego, filtr cząstek stałych), natomiast addytywne, gdy taki układ nie jest stosowany.

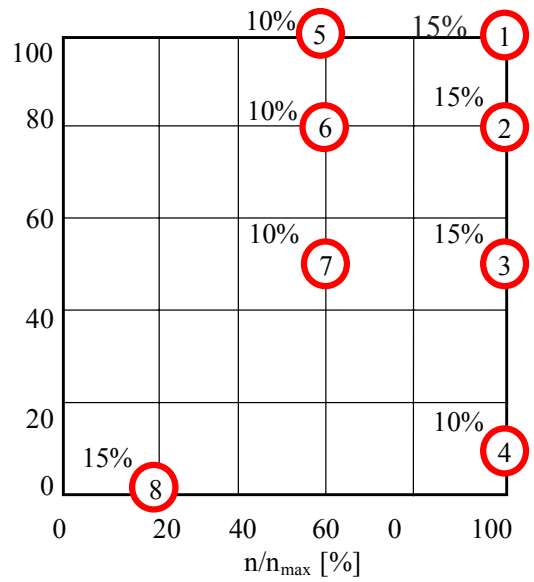

Rys. 6. Cyk1 8-fazowy NRSC (liczby przy danym punkcie pomiarowym oznaczają numer fazy i współczynnik udziału danej fazy $\mathrm{w} \%)$

Fig. 6. 8-phase NRSC cycle (the numbers nearby the measurement points denote the phase numbers and percent coefficients of the phase share)

Tablica 3. Wartości dopuszczalne emisji jednostkowej zanieczyszczeń $\mathrm{w}$ [g/(kWh)] dla etapu IIIB Table 3. Limit values of unit emission of pollutants in $[\mathrm{g} /(\mathrm{kWh})]$ for the IIIB stage

\begin{tabular}{|c|c|c|c|c|c|c|c|}
\hline \multirow[t]{2}{*}{$\begin{array}{l}\text { Klasa } \\
\text { Class }\end{array}$} & \multirow[t]{2}{*}{$\begin{array}{l}\text { Moc netto } \\
\text { Net power } \\
\mathrm{N}_{\mathrm{e}}[\mathrm{kW}]\end{array}$} & \multicolumn{2}{|c|}{$\begin{array}{c}\text { Data obowiązywania NTA/ANR } \\
\text { Effective date of NTA/ANR }\end{array}$} & \multicolumn{4}{|c|}{$\begin{array}{l}\text { Wartość dopuszczalna } \\
\text { emisji jednostkowej } \\
\text { Limit value of unit emission }\end{array}$} \\
\hline & & $\begin{array}{c}\text { dla pojazdów } \\
\text { wolnobieżnych } \\
\text { for low-speed vehicles } \\
\text { (dyrektywa/directive } \\
\text { 97/68/WE) }\end{array}$ & $\begin{array}{c}\text { dla ciagników } \\
\text { rolniczych } \\
\text { for agricultural tractors } \\
\text { (dyrektywa/directive } \\
2000 / 25 / \mathrm{WE} \text { ) }\end{array}$ & $\mathrm{CO}$ & $\mathrm{HC}$ & $\mathrm{NO}_{\mathrm{x}}$ & PM \\
\hline $\mathrm{L}$ & $130 \leq \mathrm{N}_{\mathrm{e}} \leq 560$ & $1.01 .2010 / 1.01 .2011$ & $1.01 .2010 / 1.01 .2011$ & 3,5 & 0,19 & 2,0 & 0,025 \\
\hline M & $75 \leq \mathrm{N}_{\mathrm{e}}<130$ & $1.01 .2011 / 1.01 .2012$ & $1.01 .2011 / 1.01 .2012$ & 5,0 & 0,19 & 3,3 & 0,025 \\
\hline $\mathrm{N}$ & $56 \leq \mathrm{N}_{\mathrm{e}}<75$ & $1.01 .2011 / 1.01 .2012$ & $1.01 .2011 / 1.01 .2012$ & 5,0 & 0,19 & 3,3 & 0,025 \\
\hline $\mathrm{P}$ & $37 \leq \mathrm{N}_{\mathrm{e}}<56$ & $1.01 .2012 / 1.01 .2013$ & $1.01 .2012 / 1.01 .2013$ & 5,0 & \multicolumn{2}{|c|}{4,7} & 0,025 \\
\hline Q & $130 \leq \mathrm{N}_{\mathrm{e}} \leq 560$ & $1.01 .2013 / 1.01 .2014$ & $1.01 .2013 / 1.01 .2014$ & 3,5 & 0,19 & 0,4 & 0,025 \\
\hline $\mathrm{R}$ & $56 \leq \mathrm{N}_{\mathrm{e}}<130$ & $1.01 .2014 / 1.01 .2015$ & $1.10 .2013 / 1.10 .2014$ & 5,0 & 0,19 & 0,4 & 0,025 \\
\hline
\end{tabular}

The emission should be measured at least at the beginning of the durability test after running-in of the engine and at the end of the test. Two types of the DF emission deterioration factors are used. The additive factor is defined as a difference between the measurement results at the end and at the beginning of the test. These factors are added to the emission value measured in the relevant test. In contrast, the multiplicative factor is defined as the ratio of the
W rozporządzeniu 2016/1628 [29], dotyczącym limitów emisji z pojazdów pozadrogowych (zmieniającym rozporządzenia 1024/2012 [30] i 167/2013 [31] oraz uchylające dyrektywę 97/68/WE), wprowadzono następujące kategorie silników:

- NRE - silniki do maszyn mobilnych nieporuszających się po drogach; są to silniki o mocy netto mniejszej niż $560 \mathrm{~kW}$ stosowane zamiast silników kategorii IWP, IWA, RLL lub RLR, 
measurement results at the end and at the beginning of the test. The emission values measured in the relevant test are multiplied by these coefficients. If the additive factor does not exceed 0 or the multiplicative one does not exceed 1 , the correction of the values measured in the stages IIIA, IIIB and IV is omitted. The multiplicative factors are determined if the engine is equipped with the devices reducing the emission in the exhaust system (catalytic converter, air injection into the exhaust system, diesel particulate filter), while the additive factors - when such a system is not used.

The Regulation 2016/1628 [29] related to the emission limits from non-road vehicles (amending the Regulations 1024/2012 [30] and 167/2013 [31] and repealing the Directive $97 / 68 /$ EC) specified the following engine categories:

- NRE - the engines for non-road mobile machines; these engines have a net power of less than $560 \mathrm{~kW}$ and are used instead of the engines of IWP, IWA, RLL or RLR categories;

- NRG - engines having net power above 560 $\mathrm{kW}$, intended for the generating sets;

- NRSh - SI engines for hand-held machines, having net power below $19 \mathrm{~kW}$;

- NRS - SI engines having net power below 56 $\mathrm{kW}$, not covered by the NRSh category;

- IWP - the engines intended for use in inland waterway vessels, designed for direct or indirect propulsion, having net power of at least 19 $\mathrm{kW}$;
- NRG - silniki o mocy netto ponad $560 \mathrm{~kW}$ przeznaczone do zespołów prądotwórczych,

- NRSh - silniki ZI przeznaczone do maszyn ręcznych o mocy netto mniejszej niż $19 \mathrm{~kW}$,

- NRS - silniki ZI o mocy netto mniejszej niż 56 $\mathrm{kW}$ nieobjęte kategorią NRSh,

- IWP - silniki do użytku w statkach żeglugi śródlądowej, przeznaczone do bezpośredniego lub pośredniego napędu, o mocy netto co najmniej $19 \mathrm{~kW}$,

- IWA - silniki pomocnicze na statkach żeglugi śródlądowej o mocy netto większej niż 19 kW,

- RLL - silniki do napędu lokomotyw,

- RLR - silniki do użytku w wagonach silnikowych, do ich napędu; silniki używane zamiast silników etapu V (Wartości dopuszczalne emisji... patrz tab.4) z kategorii RLL,

- SMB - silniki ZI do użytku wyłącznie w skuterach śnieżnych,

- ATS - silniki ZI do użytku w pojazdach terenowych.

W rozporządzeniu 2016/1628, zapisano, że państwa członkowskie moga udzielać homologacji typu UE i zezwalać na wprowadzanie na rynek silników kategorii RLL o maksymalnej mocy netto większej niż 2000 kW, które nie są zgodne z wartościami granicznymi emisji, a które są przeznaczone do montażu w lokomotywach poruszających się wyłącznie po odizolowanej technicznie sieci kolejowej o szerokości toru $1520 \mathrm{~mm}$. Silniki takie muszą spełniać przynajmniej

Tablica 4. Wartości dopuszczalne emisji jednostkowej zanieczyszczeń w [g/kWh] dla etapu $\mathrm{V}$

Table 4. Limit values of unit emission of pollutants in $[\mathrm{g} /(\mathrm{kWh})]$ for the $\mathrm{V}$ stage

\begin{tabular}{|c|c|c|c|c|c|c|c|c|}
\hline \multirow[t]{2}{*}{$\begin{array}{l}\text { Kategoria } \\
\text { Category }\end{array}$} & \multirow[t]{2}{*}{$\begin{array}{c}\text { Rodzaj } \\
\text { silnika } \\
\text { Engine type }\end{array}$} & \multirow[t]{2}{*}{$\begin{array}{l}\text { Moc netto } \\
\text { Net power } \\
\mathrm{N}_{\mathrm{e}}[\mathrm{kW}]\end{array}$} & \multirow{2}{*}{$\begin{array}{l}\text { Data obowiazywania } \\
\text { NTA/ANR } \\
\text { Effective date of } \\
\text { NTA/ANR }\end{array}$} & \multicolumn{5}{|c|}{$\begin{array}{l}\text { Wartość dopuszczalna emisji } \\
\text { jednostkowej } \\
\text { Limit value of unit emission }\end{array}$} \\
\hline & & & & $\mathrm{CO}$ & $\mathrm{HC}$ & $\mathrm{NO}_{\mathrm{x}}$ & $\mathrm{PM}$ & $\mathrm{PN}$ \\
\hline NRE-v/c-1 ${ }^{\text {a) }}$ & $\mathrm{ZS}$ & $\mathrm{N}_{\mathrm{e}}<8$ & $1.01 .2018 / 1.01 .2019$ & 8,0 & \multicolumn{2}{|c|}{7,5} & $0,4^{\mathrm{b})}$ & - \\
\hline NRE-v/c-2 & $\mathrm{ZS}$ & $8 \leq \mathrm{N}_{\mathrm{e}}<19$ & $1.01 .2018 / 1.01 .2019$ & 6,6 & \multicolumn{2}{|c|}{7,5} & 0,4 & - \\
\hline NRE-v/c-3 & $\mathrm{ZS}$ & $19 \leq \mathrm{N}_{\mathrm{e}}<37$ & $1.01 .2018 / 1.01 .2019$ & 5,0 & \multicolumn{2}{|c|}{4,7} & 0,015 & $1 \times 10^{12}$ \\
\hline NRE-v/c-4 & $\mathrm{ZS}$ & $37 \leq \mathrm{N}_{\mathrm{e}}<56$ & $1.01 .2018 / 1.01 .2019$ & 5,0 & \multicolumn{2}{|c|}{4,7} & 0,015 & $1 \times 10^{12}$ \\
\hline NRE-v/c-5 & $\begin{array}{c}\text { wszystkie } \\
\text { all }\end{array}$ & $56 \leq \mathrm{N}_{\mathrm{e}}<130$ & $1.01 .2019 / 1.01 .2020$ & 5,0 & 0,19 & 0,4 & 0,015 & $1 \times 10^{12}$ \\
\hline NRE-v/c-6 & wszystkie & $130 \leq \mathrm{N}_{\mathrm{e}} \leq 560$ & $1.01 .2018 / 1.01 .2019$ & 3,5 & 0,19 & 0,4 & 0,015 & $1 \times 10^{12}$ \\
\hline NRE-v/c-7 & wszystkie & $\mathrm{N}_{\mathrm{e}}>560$ & $1.01 .2018 / 1.01 .2019$ & 3,5 & 0,19 & 3,5 & 0,045 & - \\
\hline NRG-v/c-1 & wszystkie & $\mathrm{N}_{\mathrm{e}}>560$ & 1.01.2018/1.01.2019 & 3,5 & 0,19 & 0,67 & 0,035 & - \\
\hline RLL-v/c-1 & wszystkie & $\mathrm{N}_{\mathrm{e}}>0$ & $1.01 .2020 / 1.01 .2021$ & 3,5 & \multicolumn{2}{|c|}{4,0} & 0,025 & \\
\hline RLR-v/c-1 & wszystkie & $\mathrm{N}_{\mathrm{e}}>0$ & $1.01 .2020 / 1.01 .2021$ & 3,5 & 0,19 & 2,0 & 0,015 & $1 \times 10^{12}$ \\
\hline \multicolumn{9}{|c|}{$\begin{array}{l}\text { a) NRE-v1 - dotyczy silników o zmiennej prędkości obrotowej, a NRE-c1 - silników o statej prędkości obrotowej } \\
\text { NRE-v1-applies to variable speed engines, NRE-c1 - applies to constant speed engines } \\
\text { b) } P M=0,6 \mathrm{~g} / \mathrm{kWh} \text { dla silników ZS DI uruchamianych ręcznie chłodzonych powietrzem } \\
P M=0,6 \mathrm{~g} / \mathrm{kWh} \text { in case of CI DI the air-cooled engines started manually }\end{array}$} \\
\hline
\end{tabular}


- IWA - auxiliary engines on inland waterway vessels, having net power above $19 \mathrm{~kW}$;

- RLL - the locomotive engines;

- RLR - driving engines of railway motor coaches, used instead of the stage V (Limit values of unit emission ... tab.4) engines of the RLL category;

- SMB - SI engines for use only in snowmobiles;

- ATS - SI engines for use in off-road vehicles. wartości graniczne emisji, które takie silniki musiały spełniać przed wprowadzeniem na rynek na dzień 31.12.2011 r.

Dla poszczególnych kategorii silników przypisano cykle badawcze w zależności od tego czy silniki pracują przy stałej czy zmiennej prędkości obrotowej silnika (tab. 5). W zestawieniu podano również wartości okresu trwałości, który jest wymagany do określania emisji podczas badań.

Tablica 5. Cykle badawcze przypisane poszczególnych kategorii silników - etap V oraz okres trwałości emisji [29]

Table 5. Test cycles assigned to particular engine categories - the $V$ stage and the emission durability period [29]

\begin{tabular}{|c|c|c|c|c|c|}
\hline $\begin{array}{l}\text { Kategoria } \\
\text { Category }\end{array}$ & $\begin{array}{c}\text { Rodzaj silnika } \\
\text { Engine type }\end{array}$ & $\begin{array}{l}\text { Moc netto } \\
\text { Net power } \\
\mathrm{N}_{\mathrm{e}}[\mathrm{kW}]\end{array}$ & $\begin{array}{c}\text { Charakter prędkości } \\
\text { obrotowej }\end{array}$ & \begin{tabular}{|} 
Okres trwałości \\
emisji $[\mathrm{h}]$ \\
Emission \\
durability period \\
{$[\mathrm{h}]$}
\end{tabular} & $\begin{array}{c}\text { Cykl } \\
\text { badawczy } \\
\text { Test cycle }\end{array}$ \\
\hline NRE-v-1 & $\mathrm{ZS}$ & $\mathrm{N}_{\mathrm{e}}<8$ & zmienny/variable & 3000 & G2 lub C1 \\
\hline NRE-c-1 & $\mathrm{ZS}$ & $\mathrm{N}_{\mathrm{e}}<8$ & stały/constant & 3000 & D2 \\
\hline NRE-v-2 & $\mathrm{ZS}$ & $8 \leq \mathrm{N}_{\mathrm{e}}<19$ & zmienny & 3000 & $\mathrm{C} 1$ \\
\hline NRE-c-2 & $\mathrm{ZS}$ & $8 \leq \mathrm{N}_{\mathrm{e}}<19$ & stały & 3000 & D2 \\
\hline NRE-v-3 & $\mathrm{ZS}$ & $19 \leq N_{e}<37$ & zmienny & 5000 & $\mathrm{C} 1$ \\
\hline NRE-c-3 & $\mathrm{ZS}$ & $19 \leq N_{e}<37$ & stały & 3000 & D2 \\
\hline NRE-V-4 & ZS & $37 \leq \mathrm{N}_{\mathrm{e}}<56$ & zmienny & 8000 & $\mathrm{C} 1$ \\
\hline NRE-c-4 & $\mathrm{ZS}$ & $37 \leq \mathrm{N}_{\mathrm{e}}<56$ & stały & 8000 & D2 \\
\hline NRE-v-5 & wszystkie/all & $56 \leq \mathrm{N}_{\mathrm{e}}<130$ & zmienny & 8000 & $\mathrm{C} 1$ \\
\hline NRE-c-5 & wszystkie & $56 \leq \mathrm{N}_{\mathrm{e}}<130$ & stały & 8000 & D2 \\
\hline NRE-v-6 & wszystkie & $130 \leq \mathrm{N}_{\mathrm{e}} \leq 560$ & zmienny & 8000 & $\mathrm{C} 1$ \\
\hline NRE-c-6 & wszystkie & $130 \leq \mathrm{N}_{\mathrm{e}} \leq 560$ & stały & 8000 & D2 \\
\hline NRE-v-7 & wszystkie & $\mathrm{N}_{\mathrm{e}}>560$ & zmienny & 8000 & $\mathrm{C} 1$ \\
\hline NRE-c-7 & wszystkie & $\mathrm{N}_{\mathrm{e}}>560$ & stały & 8000 & D2 \\
\hline NRG-v-1 & wszystkie & $\mathrm{N}_{\mathrm{e}}>560$ & zmienny & 8000 & $\mathrm{C} 1$ \\
\hline NRG-c-1 & wszystkie & $\mathrm{N}_{\mathrm{e}}>560$ & stały & 8000 & D2 \\
\hline RLL-v-1 & wszystkie & $\mathrm{N}_{\mathrm{e}}>0$ & zmienny & 10000 & $\mathrm{~F}$ \\
\hline RLL-c-1 & wszystkie & $\mathrm{N}_{\mathrm{e}}>0$ & stały & 10000 & D2 \\
\hline RLR-v-1 & wszystkie & $\mathrm{N}_{\mathrm{e}}>0$ & zmienny & 10000 & $\mathrm{C} 1$ \\
\hline RLR-c-1 & wszystkie & $\mathrm{N}_{\mathrm{e}}>0$ & stały & 10000 & D2 \\
\hline
\end{tabular}

The Regulation 2016/1628 stipulated that Member States may grant EU-type approval and allow to introduce to the market the RLL engines with a maximum net power above $2000 \mathrm{~kW}$, not complying with the emission limit values and intended for installation in locomotives running only on technically separated rail network with $1520 \mathrm{~mm}$ track gauge. Such engines must meet at least the emission limits required before their introduction to the market as at 31/12/2011.

The test cycles have been assigned to particular engine categories depending on whether the engine operates at constant or variable speed (Table 5). The list specifies also the durability period values that is necessary in order to determine the emissions during the tests.
Dla pojazdów o zastosowaniach pozadrogowych obowiązują testy dla grupy silników podlegających testowi ISO 8178-C1, D2, F oraz G2 (rys. 8). Testy są jednakowe dla przepisów europejskich oraz amerykańskich.

\section{PODSUMOWANIE}

Konieczność ochrony środowiska stała się czynnikiem mającym bezpośredni wpływ na konstrukcje silników współczesnych pojazdów. Determinantem ich rozwoju, a równocześnie wyznacznikiem postępu technicznego w tej dziedzinie, jest zgodność z przepisami dotyczącymi emisji spalin. Do najbardziej niepożądanych związków spalin silnikowych należą cząstki 
In case of the non-road vehicles the tests for the engine group subjected to the ISO 8178-C1, D2, F and G2 tests are obligatory (Fig. 8). These tests are equal in the European and American regulations.
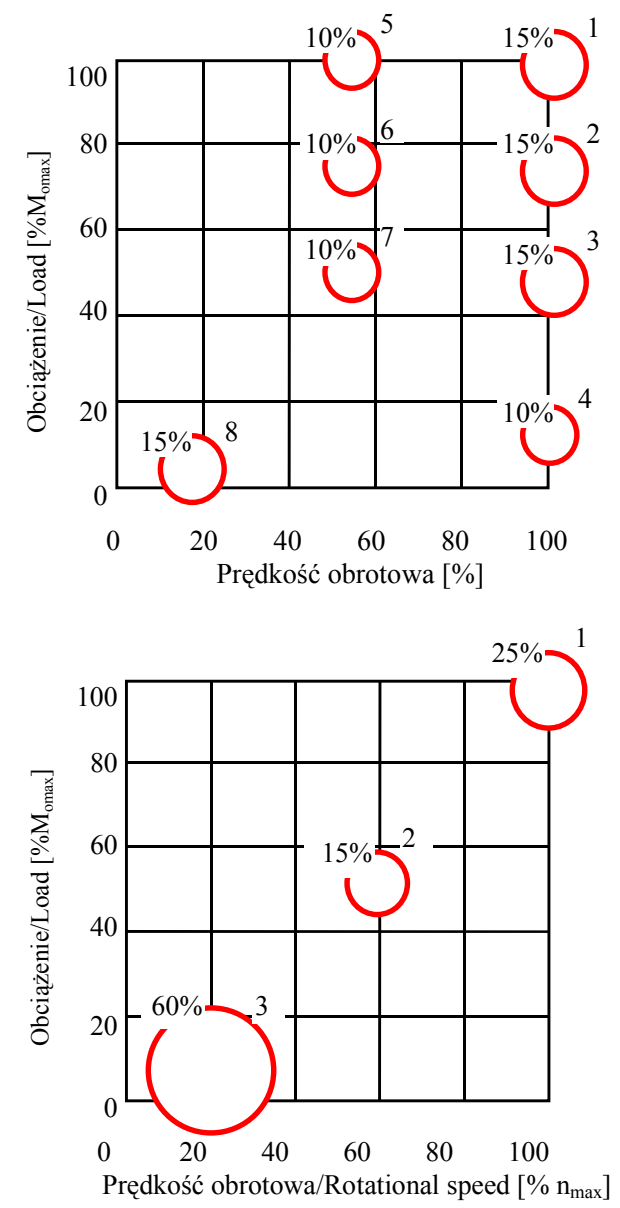

stałe i tlenki azotu. Jednoczesne zmniejszenie zawartości tych dwóch związków jest zadaniem bardzo trudnym ze względu na ich przeciwstawne właściwości.
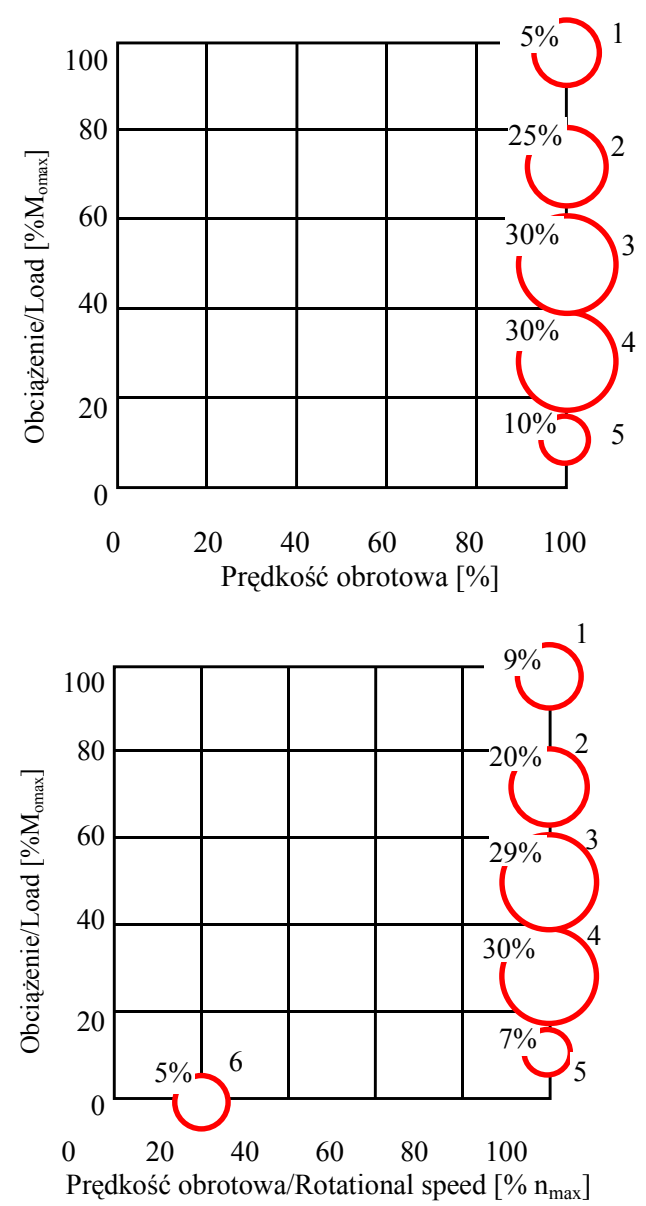

Rys. 8. Schematy testów ISO 8178: C1, D2, F, G2 do badań silników o zastosowaniach pozadrogowych

Fig. 8. Schemes of the ISO 8178: C1, D2, F, G2 tests applied to the engines of non-road vehicles

\section{Summary}

The need to protect the environment has become a factor directly affecting the design of the engines of modern vehicle. Compliance with the regulations concerning the exhaust emission is a determinant of development of these devices and, concomitantly, illustrates the technical progress in this field. Among the most undesirable engine exhaust compounds there are the particulates and nitrogen oxides. Simultaneous reduction of the content of these two compounds is very difficult, because of their opposing properties.

The new requirements regarding emission of harmful compounds from non-road vehicles (inclusive of the locomotives) imposed the obligation to determine not only the mass of the emitted particles (determined by gravimetric method by measuring the mass of the particles deposited on the filters of the sampling set which collects the exhaust gases from the dilution tunnel), but also the number of solid particles in the range of their diameters $23-300 \mathrm{~nm}$ by the
Nowe wymagania dotyczące badania emisji związków szkodliwych z pojazdów pozadrogowych (w tym lokomotyw) wprowadziły obowiązek określania nie tylko masy emitowanych cząstek, którą określa się metodą wagową przez pomiar masy cząstek osadzonych na filtrach zestawu próbkującego, pobierającego spaliny $\mathrm{z}$ tunelu rozcieńczającego, ale także liczby cząstek stałych w testach $\mathrm{C} 1$ i D2 w przedziale ich średnic 23-300 nm dla kategorii pojazdów RLR. Pomiar liczby cząstek stałych w spalinach lokomotyw wyposażonych $\mathrm{w}$ filtry cząstek stałych jest o wiele bardziej dokładny niż pomiar masy emitowanych cząstek, ze względu na trudności z dokładnym określeniem bardzo małych wartości masy cząstek. Charakteryzuje go przy tym większa powtarzalność pomiarów przy małych wartościach emisji cząstek stałych. 
C1 and D2 tests carried out for the RLR vehicle category. Measurement of the number of solid particles in the exhaust of locomotives provided with particulate filters is much more accurate than measurement of their mass, since precise measurement of very small mass is difficult. Repeatability of this measurement is much better at low particulate emission.

\section{BIBLIOGRAPHY / BIBLIOGRAFIA}

[1] Schwela D., Morawska L., Kotzias D.: Guidelines for concentration and exposure-response measurement of fine and ultrafine particulate matter for use in epidemiological studies. European Commission, World Health Organization, 2002.

[2] World Health Organization (WHO). Health effects of transport-related air pollution. Geneva 2005.

[3] Dockery D.W., Pope C.A., Xu X., Spengler J.D., Ware J.H., Fay M.E., Ferris B.G., Speizer F.E.: An association between air pollution and mortality in six U.S. cities. N. Engl. J. Med., Vol. 329, No. 24, 1993.

[4] Vedal S.: Ambient particles and health: lines that divide. Journal of the Air and Waste Management Association, Vol. 47, 1997.

[5] Merkisz J., Pielecha J., Radzimirski S.: Emisja zanieczyszczeń ze źródeł motoryzacyjnych w świetle nowych przepisów Unii Europejskiej. WKŁ, Warszawa 2012.

[6] Merkisz J:, Wptyw motoryzacji na skażenie środowiska naturalnego. Wydawnictwo Politechniki Poznańskiej, Poznań 1993.

[7] AVL Partikelseminar. Graz, 10-12.11.1993.

[8] Fritz O.: GDI engine development according EU 6. AVL Seminar, Graz 2012.

[9] Merkisz J.: Ekologiczne aspekty stosowania silników spalinowych. Wydawnictwo Politechniki Poznańskiej, Poznań 1995.

[10] Merkisz J.: Pewne uwagi o emisji czqstek statych w silnikach ZS. Ekonomiczne i ekologiczne aspekty rozwoju pojazdów samochodowych i silników spalinowych, Konmot, tom 3. Silniki spalinowe. Ekologia, paliwa alternatywne, eksploatacja, Kraków-Raba Niżna 1994.

[11] Estwood P.: Particle emissions from vehicles. John Wiley and Sons, Chichester 2008.

[12] Mayer A.: Elimination of engine generated nanoparticles. Haus der Technik Fachbuch, Expert Verlag, Renningen 2005.

[13] Bischof O.F., Horn H.-G.: Zwei Online-Messkonzepte zur physikalischen Charakterisierung ultrafeiner Partikel in Motorabgasen am Beispiel von Diesel-emissionen. Motortechnische Zeitschrift, No. 4, 1999.

[14] Merkisz J.: Emisja czastek stałych przez silniki spalinowe o zapłonie samoczynnym. Wybrane zagadnienia. Wydawnictwo Politechniki Poznańskiej, Poznań 1997.

[15] Gruber M., Klawatsch D.: Influence of motor parameters and fuel quality on particulate emissions. Vehicle Systems Technology for the Next Century. European Automotive Congress, Barcelona 30.06-2.07.1999.

[16] Kittelson D.B.: Engines and nanoparticles: a review. J. Aerosol. Sci., Vol. 29, 1998.

[17] Kittelson D.B., McMurry P., Park K., Sakurai H., Tobias H., Ziemann P.: Chemical and physical characteristics of diesel aerosol. Cambridge Particle Conference, 2002.

[18] Brook R.D., Franklin B., Cascio W., Hong Y., Howard G., Lipsett M., Luepker R., Mittleman M., Samet J., Smith S.C., Tager I.: Air pollution and cardiovascular disease. Circulation, Vol. 109, 2004.

[19] Kittelson D.B., Arnold M., Watts W.F.: Review of diesel particulate matter sampling methods. Mineapolis 1999.

[20] Hinds W.C.: Aerosol technology. John Wiley and Sons, New York 1998.

[21] Fritz O.: GDI engine development according EU 6. AVL Seminar, Graz 2012.

[22] Voltz M.: Potential of fuels and lubricants in reducing particle emissions. Elimination of Engine Generated Nanoparticles. Mayer A. (red.), Haus der Technik, Expert Verlag, Renningen 2005.

[23] Pielecha J.: Analysis of particle emission and smoke measurements in stationary cycles. PTNSS Kongres 2007; The Development of Combustion Engines, Cracow 20-23.05.2007.

[24] Directive 97/68/EC of the European Parliament and of the Council of 16 December 1997 on the approximation of the laws of the Member States relating to measures against the emission of gaseous and particulate pollutants from internal combustion engines to be installed in non-road mobile machinery. OJ L 59/1, 27.2.1998.

[25] Council Directive 88/77/EEC of 3 December 1987 on the approximation of the laws of the Member States relating to measures to be taken against the emission of gaseous pollutants from diesel engines for use in vehicles. OJ L36, 09.02.88. 
[26] Directive 2005/55/EC of the European Parliament and of the Council of 28 September 2005 on the approximation of the laws of the Member States relating to measures to be taken against the emission of gaseous and particulate pollutants from compression-ignition engines for use in vehicles, and the emission of gaseous pollutants from positive-ignition engines fueled with natural gas or liquefied petroleum gas for use in vehicles. OJ L 275 , 20.10.2005.

[27] Dyrektywa 2004/26/WE Parlamentu Europejskiego i Rady z dnia 21 kwietnia 2004 zmieniajaca dyrektywe 97/68/WE w sprawie zbliżenia ustawodawstw Państw Członkowskich odnoszacych się do środków dotyczqcych ograniczenia emisji zanieczyszczeń gazowych $i$ pyłowych z silników spalinowych montowanych $w$ maszynach samojezdnych nieporuszajacych się po drogach. Dziennik Urzędowy Unii Europejskiej L146/1.

[28] Worldwide harmonized heavy duty emissions certification procedure. Exhaust Emissions Measurement ISO Summary report. Geneva 14.01.2003.

[29] Rozporzadzenie Parlamentu Europejskiego i Rady (UE) 2016/1628 z dnia 14 września 2016 r. w sprawie wymogów dotyczacych wartości granicznych emisji zanieczyszczeń gazowych i pylowych oraz homologacji typu w odniesieniu do silników spalinowych wewnętrznego spalania przeznaczonych do maszyn mobilnych nieporuszajacych się po drogach, zmieniajace rozporzqdzenia (UE) $\mathrm{nr}$ 1024/2012 i (UE) $\mathrm{nr}$ 167/2013 oraz zmieniajace i uchylajace dyrektywę 97/68/WE.

[30] Rozporzqdzenie Parlamentu Europejskiego i Rady (UE) nr 1024/2012 z dnia 25 października 2012 r. w sprawie współpracy administracyjnej za pośrednictwem systemu wymiany informacji na rynku wewnętrznym i uchylajace decyzje Komisji 2008/49/W.

[31] Rozporzadzenie Parlamentu Europejskiego i Rady (UE) nr 167/2013 z dnia 5 lutego 2013 r. w sprawie homologacji i nadzoru rynku pojazdów rolniczych i leśnych. 